\title{
ANALISIS YURIDIS TENTANG KEBIJAKAN HOLDING TERHADAP BADAN USAHA MILIK NEGARA (BUMN) SEKTOR PERTAMBANGAN
}

\author{
Rustam Magun Pikahulan \\ IAIN Parepare \\ rushpikahulan23@gmail.com
}

\author{
Abd Karim Faiz \\ IAIN Parepare
}

\begin{abstract}
On November 29, 2017 the deed inbreng was signed by shareholders of PT Timah (Persero) Tbk (TINS), PT Aneka Tambang (Persero) Tbk (ATNM) and PT Bukit Asam (Persero) Tbk (PTBA) and approved the transfer of government shares to PT Indonesia Asahan Inalum (Persero) as well as evidence that the BUMN Mining Holding is officially formed. In the EGMS conducted by the three SOEs, it was agreed that the amendment to the articles of association was also related to the transfer of majority ownership from the original Republic of Indonesia to the ownership of PT Inalum (Persero) whose entire shares were owned by the State. The legal basis used by the government in forming the SOE holding is contained in Government Regulation Number 72 of 2016 concerning Amendment to Government Regulation Number 44 of 2005 concerning Procedures for Participation and Administration of State Capital in State-Owned Enterprises and Limited Liability Companies.
\end{abstract}

Keywords: Holding, BUMN, Mining

\begin{abstract}
Abstrak: Pada tanggal 29 November 2017 akta inbreng telah diteken oleh pemegang saham PT Timah (Persero) Tbk (TINS), PT Aneka Tambang (Persero) Tbk (ATNM) dan PT Bukit Asam (Persero) Tbk (PTBA) dan menyetujui perpindahan saham pemerintah ke PT Indonesia Asahan Inalum (Persero) serta menjadi bukti bahwa Holding BUMN Tambang secara resmi terbentuk. Dalam RUPSLB yang dilakukan oleh ketiga BUMN tersebut telah disepakati juga perubahan anggaran dasar sehubungan dengan telah beralihnya kepemilikan mayoritas dari semula Negara RI menjadi kepemilikan PT Inalum (Persero) yang seluruh sahamnya dimiliki Negara. Dasar hukum yang dipakai oleh pemerintah dalam pembentukan holding BUMN tersebut tertuang dalam Peraturan Pemerintah Nomor 72 Tahun 2016 tentang Perubahan Atas Peraturan Pemerintah Nomor 44 Tahun 2005 tentang Tata Cara Penyertaan dan Penatausahaan Modal Negara pada Badan Usaha Milik Negara dan Perseroan Terbatas.
\end{abstract}

Kata Kunci: Holding, BUMN, Tambang 
Rustam Magun Pikahulan dan A6d Karim Faiz:

Analisis Yuridis tentang Kebijakan Holding Terhadap Badan Usaha Milik $\mathcal{N}$ egara $(\mathcal{B} U \mathcal{M} \mathcal{N})$ Sektor Pertambangan

\section{PENDAHULUAN}

Dalam sebuah proses membangun terdapat beberapa aspek serta dimensi harus diperhatikan, dalam hal ini termasuk politik, ekonomi, sosial, hukum, budaya, dan pertahanan keamanan. Di antara aspek dan dimensi tersebut, pembangunan ekonomi menjadi salah satubagian yang lebih menonjol dan konkrit karena dampaknya langsung terasa pada kehidupan manusia yaitu terkait dengan kebutuhan hidup.Oleh sebab itu, pembangunan lebih diidentikan dengan pembangunan ekonomi yang tujuannya adalah untu melihat kesejahteraan suatu Negara. Heidrachman Ranupandojo dalam pendapatnya menyatakan bahwa, dalam kehidupan bernegara, aspek atau dimensi perekonomian memegang perananan penting diantara semuaaspe atau dimensi yang lain. ${ }^{1}$ Sehingga pandangan ini menunjukan bahwa bagian terpenting dari keseluruhan pembangunan dalam sebuah kehidupan bernegara adalah pembangunan ekonomi.Namun dalam hal ini, untukmembangunperekonomianserta pelaksanaan kegiatan ekonomi selalu membutuhkan adanya stabilitas, sehingga untuk menjamina terwujudnya stabilitas tersebut maka diperlukan kehadiran hukum sebagai alat pengatur dan pembuat regulasi.Dalam membangunperekonomian suatu negara membutuhkan adanya tuntunan agar dapat berjalan secara konsisten kedalam satu kerangka atau pola pembangunan, dan tuntunan itu juga diberikan oleh hukum.

Dalam menyelenggarakan perekonomian nasional yang menjadi pilar penting dalam pembangunan suatu negara adalah mewujudkan kehidupan masyarakat untuk menuju kesejaheraan.Disinilah yang kemudian dibutukan negara adalah Negara hadir sebagai pelaku ekonomi untuk mewujudkan pembentukan Badan Usaha Milik Negara (BUMN).tidak dapat dipungkiri bahwa sejak dekade pertama revolusi kemerdekaan sampai sekarang, BUMN telah memberikan kontribusi yang sangat besar bagi pembangunan dan perkembangan perekonomian nasional. Jika mau dilihat pada masa-masa awal kemerdekaan, semua sektor usaha swasta belum bekerja secara efektifdikarenakan situasi politik dan ekonomi setelah masa perjuangan kemerdekaan yang belum tertata dengan baik, disinilah BUMN menjadi satu-satunya tumpuan bagi program penyediaan 
Rustam Magun Pikahulan dan A6d Karim Faiz:

Analisis Yuridis tentang Kebijakan Holding Terhadap Badan Usaha

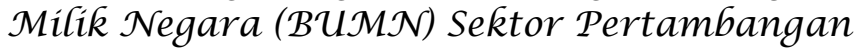

barang dan jasa termasuk juga pengadaan infrastruktur lainnya oleh pemerintah. ${ }^{2}$ Bukan itu saja, keadiran BUMN juga sebagai salah satu sumber penerimaan negara yang cukup signifikan dalam bentuk berbagai jenis pajak, deviden dan hasil privatisasi. ${ }^{3}$

Tujuan utama Pemerintah Indonesia mendirikan BUMN, adalah yang pertama tujuan yang bersifat ekonomi dan yang kedua tujuan yang bersifat sosial. Dalam tujuan yang bersifat ekonomi, BUMN didirikan dengan tujuan untuk mengelola dan mengatur sektor-sektor bisnis yang bersifat strategis agar tidak dikuasai sebagian pihak atau oleh pihak-pihak tertentu. Bidang-bidang usaha yang di maksudkan adalah sebagaimana yang terdapat dalam pasal 33 UUD 1945, yang berkaitan dengan hajat hidup orang banyak seperti perusahaan listrik, minyak dan gas bumi, bidang-bidang tersebut seharusnya dikuasai oleh BUMN. Yang kedua tujuan adanya BUMNsecara sosialdiantaranya adalah BUMN menciptakan lapangan kerja melakukan upaya serta usaha untuk meningkatkan perekonomian lokal. Hal ini dilakukan dengan cara menciptakan lapangan kerja dicapai melalui perekrutan tenaga kerja oleh BUMN. Sedangkan upaya untuk membangkitkan dan meningkatkan perekonomian lokal, dilakukan dengan cara melakukan dan mengikut sertakan masyarakat sebagai mitra kerja dalam mendukung kelancaran proses kegiatan usaha. ${ }^{4}$

Dalam Pengelolaan BUMN tidak selamanya berjalan secara efektif, tetapi juga adanya pasang surut dari masa ke masa dengan berbagai tantangan yang dihadapi baik dari dalam negeri maupun dari luar negeri.Ole karena itu, sudah banyak program maupun kebijakan perbaikan dan pembinaan terhadap BUMN telah di terbitkan dan dikeluarkan oleh pemerintah melalui berbagai Undangundang, Peraturan Pemerintah, Keputusan Presiden serta aturan-aturan secara teknis serta aturan pelaksanaan dibawahnya. Bahkan dalam membuat kebijakan tertentu, proses tersebut juga telah memunculkan berbagai macam istilah dalam rangka pengelolaan dan pembinaan kinerja BUMN diantaranya adalah sepertirestrukturisasi,profitisasi,deregulasi, debirokratisasi, privatisasi bahkan sampai pada tahapan yang disebut Holdingnisasi. ${ }^{5}$ Kebijakan Pemerintah pada sektor pertambangan, telah melakukan holdingnisasi terhadap tiga perusahan 
Rustam Magun Pikahulan dan A6d Karim Faiz:

Analisis Yuridis tentang Kebijakan Holding Terhadap Badan Usaha Milik $\mathcal{N}$ egara $(\mathcal{B} U \mathcal{M} \mathcal{N})$ Sektor Pertambangan

BUMN yaitu dari PT Bukit Asam Tbk (PTBA), PT Timah Tbk (TINS) dan PT Aneka Tambang Tbk (ANTM).Hal tersebut menjadikan beralihnya saham milik negara pada tiga perusahaan tersebut ke induk perusahan(holding) BUMN Tambang yaitu PT Indonesia Asahan Alumunium (Inalum).PT Bukit Asam Tbk, PT Timah Tbk, dan PT Antam Tbkdalam melepas statusnya Persero setelah ketiga perusahaan BUMN Tambang tersebut digabungkan menjadi anggota Holding BUMN dari PT Inalum yang bergerak pada sektor Pertambangan. Sehingga jika dilihat lebih mendalam melalui sudut pandang hukum dan bisnis, dengan dihapusnya status Persero ketiga perusahan tersebut meberikan dua konsekuensi baikmeberikan keuntunganbuat pemerintahmaupun berpotensi merugikan pemerintahpada saat yang bersamaan. ${ }^{6}$

Menurut Yudhistira Bhima Adhinegara, salah satu peneliti dari Institute for Development of Economics \& Finance (Indef), berpendapat bahwa dampak yang akan dirasakan dari dicabutnya status Persero adalah dapat menjadikan perusahaan lebih mudah melakukan aksi atau kegiatan korporasi (corporate action) dan ini benar-benar tak sebanding dengan ketika ketiga perusahaan tersebut masih menyandang status perusahaan plat merah. Akan tetapi, keluwesan aksi korporasi yang dilakukan oleh perusahaan tersebut setelah yang tadinya brsstatus Persero dicabut, akanterasa riskan karena dalam prosesnya tersebut akan mengurangi pengawasan yang awalnya menjadi dari kewenangan pemerintah dan DPR. ${ }^{7}$ Yang dimaksudnya Bhima dalam pendapatnya diatas adalah dengan berkurangnya aksi korporasi dapat menjadikanPT Inalum (Persero) selaku induk Holding dengan mudah untuk mencari pendanaan dalam menyelesaikan tugastugas yang diamanatkan pemerintah kepada Holding BUMN yang bergerak pada Industri Pertambangan tersebut. Akan tetapi, jika dalam menjalani penugasan yang telah ditugaskan tersebut oleh pemerintah berujung pada dikorbankannya tiga anggota Holding BUMN tersebut karena dapat membuat beban ketiganya semakin berat.Holding tiga BUMN tersebut tertuang dalam Peraturan Pemerintah Noomor 47 Tahun 2017 tentang Penambahan Penyertaan Modal Negara Republik Indonesia ke dalam Modal Saham PT Inalum. PT Antam, PT Timah dan PTBA. 
Rustam Magun Pikahulan dan A6d Karim Faiz:

Analisis Yuridis tentang Kebijakan Holding Terhadap Badan Usaha

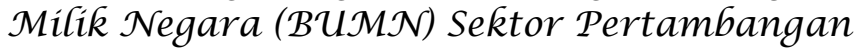

Ide tentang holding BUMN sudah digagas pada masa Tanri Abeng masih menjabat sebagai Menteri BUMN 1998-1999.Pada saat itu hal-hal yang menyangkut denganpenyusunan Master Plan BUMN dijadikan sebagai roadmap yang bertujuan untuk penciptaan nilai (value creation) BUMN, serta adanya keterlibatan konsultan internasional. Namun setelah itu, pengaplikasian dari kebijakan tersebut belum dijalankan dengan spenuhnya, hal inidikarenakan terjadiberbagai penyimpanganpolitik dan berpengaruh pada proses untuk mempercepat atau menjalankanupaya untuk penciptaan nilai. Ini menandakan bahwa, pengelolaan BUMN belum dapat dipisahkan secara tuntas dari kekuasaan yang bersumber dari kekuatan politik dan dimensi kepentingan politik masih berpengaruh dalam pengelolaan BUMN. ${ }^{8}$ Oleh karena itu, Holding sendiri merupakan konsep untuk merampingkan sejumlah BUMN di Indonesia, tujuan dari adanya holding BUMN dengan jalan melakukan terhadap pengelompokan BUMN ke setiap sektor atau industri. Oleh karena itu berangkat dari permasalahan yang dipaparkan diatas maka permasalahan yang kemudia menjadi menarik untuk dikaji adalah apakah kebijakan Holding pada sektor pertambangan tidak bertentangan dengan ketentuan Perundang-undangan di Indonesia dan bagaimana kedudukannya dalam perundang-undangan di Indonesia.

\section{PEMBAHASAN}

\section{A. Kebijakan Holding Terhadap Badan Usaha Milik Negara (BUMN)Sektor Pertambangan}

Holding BUMN industri pertambangan menjadi kebijakan pertama di era pemerintahan Jokowi, serta menghadirkan diskusi panjang dalam setiap kalangan dalam hal ini termasuk juga masyrakat selaku warga Negara. Pemerintah membuat kebijakan ini dengan Dasar hukum sebagaimana yang tertuang dalam Peraturan Pemerintah Nomor 72 Tahun 2016 tentang Perubahan Atas Perturan Pemerintah Nomor 44 Tahun 2005 yang tentang Tata Cara Penyertaan dan Penatausahaan Modal Negara pada Badan Usaha Milik Negara dan Perseroan Terbatas.Dengan adanya peralihan saham milik negara pada ketiga BUMN tersebut ke PT Indonesia Asahan Alumunium (Inalum) menjadikan induk holding 
Rustam Magun Pikahulan dan A6d Karim Faiz:

Analisis Yuridis tentang Kebijakan Holding Terhadap Badan Usaha Milik $\mathcal{N}$ egara $(\mathcal{B} U \mathcal{M} \mathcal{N})$ Sektor Pertambangan

BUMN Tambang dipegang oleh PT Inalum yang beranggotakan ketiga perusahan tersebut. namun jika pada Mengacu pada PP No.72 Tahun 2016, maka PT Antam, PT Timah dan PTBA disetarakan dengan BUMN dari segi perlakuannya, hal ini dikarenakan saham dwi warna dari ketiga BUMN tersebut masih dipegang pemerintah. Bukan itu saja, ketiganya juga masih akan tetap ditugaskan oleh pemerintah dalam melayani kepetingan public atau umum selayaknya masih menyandang staus BUMN atau sebelum di holdingkan. Ditambah lagi ketiganya masih tetap mendapatkan kebijakan khusus oleh negara atau pemerintah, termasuk dalam pengelolaan sumber daya dengan perlakuan tertentu sebagaimana diberlakukan bagi BUMN.

Hambra yang menjabat sebagai Deputi Bidang Infrastruktur Bisnis Kementerian BUMN, dalam keterangan tertulis menyampaikan bahwa, "seagala yang menyangkut dengan perusahaan anggota holding dengan hal strategis yang dilakukannya, negara masih akan tetap mengontrol sama halnya dengan sebelum beralih menjadi anggota holding, termasuk dalam hubungannya dengan DPR apabila akan diprivatisasi". 9 Hambra menambahkan berubahnya status ketiga anggota holding tersebut, tidak akan berpengaruh pada perlakuan pemerintah terhadap ketiga eks BUMN tersebut dan tetap diperlakukan sama seperti masih bersatus sebagai perusahan BUMN. Karena secara tidak lansung melalui PT Inalum (Persero) yang 100\% sahamnya dimiliki oleh Negara dan secara langsung melalui saham dwiwarna pemerintah bisa melakukan pengawasan.

Sejak di keluarkannya Peraturan Pemerintah Nomor 47 Tahun 2017, menjadikan holdingnisasi BUMN sektor pertambangan secara resmi berdiri dan induk perusahaan (holding) BUMN dipegang oleh PT Inalum, serta PT Antam Tbk, PTBA Tbk, dan PT Timah Tbk, masuk sebagai anak perusahaan (anggota holding). Menurut menteri BUMN Rini Soemarno, tujuan dibentuknya holding BUMN sector atau indutri pertambangan untuk meningkatkan pendanaan dan kapasitas usaha, pengelolaan sumber alam mineral serta batubara, untuk meningkatan nilai tambah tersebut dilakukan dengan cara meningkatkan kandungn lokal dan melalui proses hilirisasi, dengan dilakukannya sinergitas dari penggunaan efisiensi biaya ${ }^{10}$ Rini menambahkan, kebijakan pembentukan 
Rustam Magun Pikahulan dan A6d Karim Faiz:

Analisis Yuridis tentang Kebijakan Holding Terhadap Badan Usaha Milik $\mathcal{N}$ egara $(\mathcal{B} U \mathcal{M} \mathcal{N})$ Sektor Pertambangan

Holding BUMN sector/Industri Pertambangan adalah jawaban untuk menghadapi tantangan persaingan global yang semakin kuat dan cepat. Olehnya itu dengan adanya keberadaan Holding BUMN Industri Pertambangan diharapkan akan memberi manfaat yang besar, tentunya bukan hanya bagi perusahaan holding dan anak perusahaan anggota holding, namun juga bagi pemerintah dan masyarakat.

Disatu sisi kritik terhadap kebijakan pemerintah dilakukan oleh pengamat kebijakan publik Agus Pambagio, dia berpendapat bahwa perubahan status tiga BUMN itu menjadi nonpersero merupakan adalah salah satu upaya untuk melakukan swastanisasi oleh pemerintah terhadap perusahaan milik Negara dibawah kendali BUMN. Bukan hanya itu saja Agusjuga melakukan desakan terhada pemerintah untuk melakukan evaluasi ulang terhadapkebijakan yang dilakukan untuk menjadikanketiga BUMN tersebut berstatus non Persero.Bukan hanya itu saja, bahkan dalam keterangannya dia mengidikasikan adanya oknum Negara yang mengupayakan ini tanpa izin DPR untuk menjual saham. Dalam lanjutan keterangan agus menambah bahwa, bersama Mahfud MD mereka sudah melakukan upaya pencegahan dan bahkan dengan cara mengajukan judicial review ke MA akan tetapi tapi kalah saat diputuskan MA. ${ }^{11}$ Menurut agus, Pemerintah telah melakukan sebuah kebijakan yang bertentangan dengan UndangUndang BUMN, Undang-UndangPerseroan Terbatas maupun Undang-Undang Nomor 17 Tahun 2003 tentang Keuangan Negara. Karena telah menjadikan Peraturan Pemerintah Nomor 72 tahun 2016 sebagai landasan untuk menghapus status Persero pada PT Antam, PTBA dan PT Timah, yang secara yuridis implementasi holding BUMN bertentangan dengan ketiga Undang-Undang tersebut.

Perlu diketahui bahwa kebijakan tentang holding BUMN tiga perusahan industry pertambangan tersebut, terjadi perselisihan pendapat antara pemerintah dengan pihak DPR. ${ }^{12}$ Menurut Inas Nasrullah Zubir selaku Wakil Ketua Komisi VI DPR RI, Komisi VI terpecah dan berbeda pendapat dalam memandang soal dasar hukum pembentukan holding BUMN.Yang sepakat dengan pemerintah mendukung agar Peraturan PemerintahNomor 72 tahun 2016 tetap dipakai, yang tidak sejalan dengan Pemerintah tetap masih bersikeras dalam menentang 
Rustam Magun Pikahulan dan A6d Karim Faiz:

Analisis Yuridis tentang Kebijakan Holding Terhadap Badan Usaha

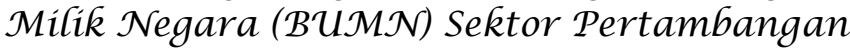

Pemerintah soal dasar hukum pembentukan holding tersebut. Pada Pasal 2A ayat (1) Peraturan Pemerintah Nomor 72 tahun 2016, menyebutkan adanya penyertaan modal negara yang sumbernya diambl dari kekayaan Negara tanpa persetujuan DPR. Yang dilakukan dalam bentuk saham milik negara pada BUMN atau PT kepada BUMN atau PT lain dilakukan oleh Pemerintah Pusat tanpa melalui mekanisme APBN. Padahal, terkait dengan kekayaan negara yang diubah menjadi aset BUMN dan PT, dalam hal ini pemerintahtidak dapat langsung bertindak tanpaadanyapembahasan dan persetujuan dengan DPR sebagaimana diatur dalam UU Nomor 17 tahun 2003. Sementara itu sebagaian DPR yangtidak sepakat dengan kebijakan pemerintah beralasan bahwa, anak perusahaan BUMN bukanlah berasal dari BUMN sebagaimana diatur dalam UU Nomor 19 Tahun 2003 Tentang BUMN. Mereka memandang bahwa, secara konstitusi dalam UUD 1945 Pasal 33 BUMN mendapatkan hak yang sama dalam pengelolaan sumber daya strategis. Oleh karena itu anak perusahaan BUMN tidak dapat diperlakukan sama dengan BUMN serta seluruh aset strategis nasional harus dikelola oleh negara melalui BUMN. ${ }^{13}$

Roadmap BUMN tahun 2015-2019 telah dicantumkan arah pembangunan BUMN jangka menengah serta pembentukan holding BUMN industri pertambangan yang sesuai dengan strategi dan rencana yang telah diatur.Hal ini di sampaikan oleh Fajar Harry Sampurno yang menjabat sebagai Bidang Usaha Pertambangan, Industri Strategis dan Media Kementerian BUMN.Menurut Fajar, menjalankan program hilirisasi dan kandungan lokal, sebagai sarana untuk BUMN industry pertambangan menjadi salah satu perusahaan kelas dunia. oleh karena itu, dengan adanya sinergi BUMN sektor pertambanganakan dapat mengerjakan sejumlah proyek bernilai besar. Dengan pembangunan sejumlah proyek besartersebut, tentunya membutuhkan pembiayaan dalam jumlah yang besar, sehingga pemerintah menilai Holding BUMN Industri Pertambangan adalah solusi atas besarnya pembiayaan tersebut. ${ }^{14}$

\section{B. Analisis Yuridis Terhadap Kebijakan Holding Badan Usaha Milik Negara (BUMN) Sekor Pertambangan}


Rustam Magun Pikahulan dan A6d Karim Faiz:

Analisis Yuridis tentang Kebijakan Holding Terhadap Badan Usaha

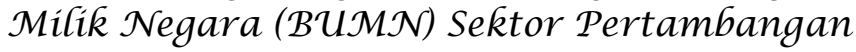

Disahkannya Holding BUMN sector pertambangan yang merupakan kebijakan pemerintah dikeluarkan berdasarkan Peraturan Pemerintah Nomor 47 Tahun 2017 Tentang Penambahan Penyertaan Modal Negara Republik Indonesia Ke Dalam Modal Saham Perusahaan Perseroan (Persero) PT Indonesia Asahan Aluminium. Pemerintah membentuk holding BUMN industri tambang dengan mengalihkan saham pemerintah dari PT Aneka Tambang (Antam) Tbk sebesar 65\%, PT Bukit Asam Tbk sebesar 65,02\%, PT Timah Tbk sebesar 65\%, kepada induk holding yakni PT Inalum (Persero). Tujuan pemerintah membentuk holding BUMN industri pertambangan dengan tujuan dan harapan agar dapat meningkatkan kapasitas usaha perusahan perseroan serta memperkuat permodalan. Hal tersebuttelah ditegaskan melalui dasar pertimbangan yang dipakai oleh pemerintah dalam membentuk holding ketiga BUMN ini, sebagaimana yang terdapat dalamPeraturan Pemerintah Nomor 47 Tahun 2017. Pertimbangan yang terdapat dalam Peraturan Pemerintah Nomor 47 Tahun 2017 bertujuan untuk meningkatkan kapasitas usaha Perusahaan Perseroan (Persero) PT Indonesia Asahan Aluminium dan memperkuat struktur permodalan, dasar inilah yang kemudian dipakai oleh pemerintah untuk melakukan penambahan Penyertaan Modal Negara Republik Indonesia ke dalam modal saham Perusahaan Perseroan (Persero) PT Indonesia Asahan Aluminium yang sumber modalnya berasal dari pengalihan seluruh saham Seri B milik Negara Republik Indonesia pada Perusahaan Perseroan (Persero) PT Aneka Tambang Tbk, Perusahaan Perseroan (Persero) PT Bukit Asam Tbk, dan Perusahaan Perseroan (Persero) PT Timah Tbk serta seluruh saham milik Negara Republik Indonesia pada PT Freeport Indonesia. ${ }^{15}$

Perusahaan tambang pelat merahyang terbentuk dalam Holding BUMN, terdiri dari tiga perusahan besar dibawah BUMN dilakukan dengan pengalihan saham ketiga BUMN tersebut sekaligus menghilangkan status persero dari ketiga perusahan tersebut. Akan tetapi,Gatot Trihargo(Deputi Bidang Usaha Jasa Keuangan, Jasa Survei, dan Konsultan Kementerian BUMN)berpendapat bahwa, kontrol pemerintah tetap ada dan telah tertuang jelas dalam Peraturan Pemerintah (PP) Nomor 72 Tahun 2016 terkait Tata Cara Penyertaan dan Penatausahaan 
Rustam Magun Pikahulan dan A6d Karim Faiz:

Analisis Yuridis tentang Kebijakan Holding Terhadap Badan Usaha

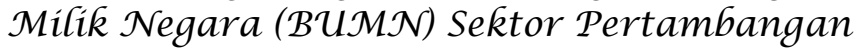

Modal Negara pada BUMN dan Perseroan Terbatas (PT). ${ }^{16}$ Sehingga dasar hukum yang dipakai oleh pemerintah dengan adanya holding ketiga BUMN yang bergerak di bidang pertambangan adalah Pada Pasal 2A ayat (1) Peraturan Pemerintah Nomor Nomor 72 Tahun 2016 Tentang Perubahan Atas Peraturan Pemerintah Nomor 44 Tahun 2005 Tentang Tata Cara Penyertaan Dan Penatausahaan Modal Negara Pada Badan Usaha Milik Negara Dan Perseroan Terbatas. Pasal tersebut menegaskan bahwa, Penyertaan Modal Negara yang berasal dari kekayaan negara berupa saham milik negara pada BUMN atau Perseroan Terbatas sebagaimana dimaksud dalam Pasal 2 ayat (2) huruf d kepada BUMN atau Perseroan Terbatas lain, dilakukan oleh Pemerintah Pusat tanpa melalui mekanisme Anggaran Pendapatan dan Belanja Negara. ${ }^{17}$ Oleh sebab itu pemerintah merasa bahwadengan pasal tersebut, maka pemerintah dapat menetapkan holding BUMN pertambangan tanpa persetujuan DPR.

Selanjutnya pada Pasal 2A ayat (2) telah menerangkan secara jelas bahwa, ketika kekayaan negara berupa saham milik negara pada BUMN dijadikan penyertaan modal negara pada BUMN lain. ${ }^{18}$ Oleh karena itu maka, sebagian besar saham tersebut dimiliki oleh BUMN lain, maka BUMN tersebut menjadi anak perusahaan BUMN dengan ketentuan negara wajib memiliki satu saham dengan hak istimewa yang diatur dalam anggaran dasar. Dasar inilah yang dijadikan Pemerintah, dengan menjadikan ketiga BUMN ini di bawah PT Inalum dengan beralasan bahwa PT Inalum terdapat saham Negara.Menurut pengamat BUMN sekaligus mantan Sekretaris Jenderal BUMNSaid Didumemaparkan bahwa, ada empat poin yang tak luntur dari peran tiga perusahaan tambang tersebut, diantaranya: ${ }^{19}$

1) ketiganya bersama Inalum tetap akan diawasi oleh pemerintah dan DPR, meski statusnya sebagai anak perusahaan. Bahkan, tidak hanya yang merupakan perusahaan pelat merah, perusahaan swasta pun sebenarnya bisa diawasi, terutama yang bermitra dengan pemerintah.

2) Antam Cs tetap akan tunduk pada aturan main Kementerian BUMN selaku perpanjangan tangan pemerintah. Karena pemerintah memiliki saham di perusahaan tersebut. 
Rustam Magun Pikahulan dan A6d Karim Faiz: Analisis Yuridis tentang Kebijakan Holding Terhadap Badan Usaha Milik $\mathcal{N}$ egara $(\mathcal{B} U \mathcal{M} \mathcal{N})$ Sektor Pertambangan

3) penjualan aset atau privatisasi tetap melalui persetujuan pemerintah dan DPR. Sebab, seperti halnya poin kedua, tetap mengikuti aturan Kementerian BUMN dari segi hak dan kewajibannya.

4) penghapusan status persero atau tidak lagi sebagai BUMN tetap berhak mendapat hak-hak istimewa sebagai mantan BUMN. Sebab, seperti poin kedua, semuanya tetap sama.

Hilangnya statu Persero dari ketiga BUMN tambang tersebut yang diributkan dan mendapatkan banyak kritikan dari berbagai pihak, menurut penulis secara hukum memang hilang status persero tersebut menjadikan ketiga BUMN tersebut tidak lagi sebagai perusahan persero akan tetapi disatu sisi masih dapat dikendalikan oleh pemerintah hal ini telah diterangkan dalam Pasal 1 ayat (1) Peraturan Pemerintah Nomor 47 Tahun 2017 yaitu Negara Republik Indonesia melakukan penambahan penyertaan modal ke dalam modal saham Perusahaan Perseroan (Persero) PT Indonesia Asahan Aluminium, yang statusnya sebagai Perusahaan Perseroan (Persero) ditetapkan berdasarkan Peraturan Pemerintah Nomor 26 Tahun 2014 tentang Penetapan PT Indonesia Asahan Aluminium Sebagai Perusahaan Perseroan (Persero) PT Indonesia Asahan Aluminium. ${ }^{20}$ Jadi menurut penulis ketiga BUMN tersebut masih tetap dalam pengawasan Negara dikarenakan status dari PT Indonesia Asahan Aluminium Sebagai Perusahaan Perseroan (Persero)sekaligus induk holding dan ketiga BUMN tersebut berstatus sebagai anggota holding.

Selain itu juga menurut penulis kendali Pemerintah terhadadap ketiga BUMN tersebut diperkuat dengan Pasal 3 Peraturan Pemerintah Nomor 26 Tahun 2014 tentang Penetapan PT Indonesia Asahan Aluminium Sebagai Perusahaan Perseroan (Persero) PT Indonesia Asahan Aluminiumdalam pasal tersebut menerangkan bahwa, dengan adanya pengalihan saham Seri B, negara tetap harus melakukan kontrol terhadap Perusahaan Perseroan (Persero) PT Aneka Tambang Tbk, Perusahaan Perseroan (Persero) PT Timah Tbk, dan Perusahaan Perseroan (Persero) PT Bukit Asam Tbk melalui kepemilikan saham Seri A dwi warna dengan kewenangan sebagaimana diatur dalam Anggaran Dasar. ${ }^{21}$ jadi menurut penulispengalihan saham ketiga BUMN sektor pertambangan tersebut memang 
Rustam Magun Pikahulan dan A6d Karim Faiz:

Analisis Yuridis tentang Kebijakan Holding Terhadap Badan Usaha Milik $\mathcal{N}$ egara $(\mathcal{B} U \mathcal{M} \mathcal{N})$ Sektor Pertambangan

menghilangkan status Persero, akan tetapi masih menjadi anak perusahan dari PT Inalum yang sahamnya $100 \%$ milik Negara yang merupakan BUMN, dan disitulah Negara melalui pemerintah masih dapat melakulan kontrol terhadap ketiga BUMN tersebut selaku atau bersatus sebagai anggota holding.

Kementerian BUMN selaku kementrian yang mengatur dan mengontrol setiap kegiatan dari perusahan yang bersatus BUMN menjelaskan bahwa, setidaknya ada enam manfaat pembentukan holding BUMN.Pertama, kemandirian keuangan tanpa penambahan Penambahan Modal Negara (PMN).Kedua, membuka lapangan kerja baru.Ketiga, mendorong ketahanan pangan.Keempat, mempercepat penyediaan perumahan rakyat.Kelima, dividen dan pajak pemerintah meningkat dan keenam, infrastruktur efisien dan terintegrasi. ${ }^{22}$ Dengan adanya Holding tambang akan meningkatkan keuntungan termasuk meningkatkan hilirisasi, sebagaimana yang dijelaskan oleh Budi Gunadi Sadikin selaku dirut Inalum yang sebelumnya menjadi staf khusus Menteri BUMN.Kemudian menurutnya lagi bahwa, setelah holding tambang terbentuk maka akan banyak produk tambang yang memiliki nilai terbaik dan akan dipasarkan ke berbagai tempat dan akan memperkuat sinergi antar unit. Selain itu juga holding tambang diperkirakan total asetnya bisa mencapai Rp 90 triliun dan setelah efektif, kekuatan aset tersebut dapat membuka peluang makin besar untuk ambil bagian dalam divestasi saham Freeport Indonesia. Dan jika berhasil, kekayaan BUMN tambang akan bertambah menjadi sekitar Rp 200 triliun dan akan memperkuat struktur permodalan dari perusahan holding oada sector pertambangan tersebut. ${ }^{23}$

Jadi kebijakan pemerintah dalam pembentukan holding ketiga BUMN tambang tersebut menurut pendapat penulis ini merupakan salah satu bagian dari upaya untuk mendukung Pemerintah dalam meningkatkan pendapatan Negara.Hal ini sejalan dan diperkuat dengan pendapat dariToto Pranoto dan Willem A. Makaliwe (Tim Riset Lembaga Management FE UI). ${ }^{24}$ Yang dalam paparannya mereka menyatakan bahwa pembentukan holding BUMN akan meningkatkan fleksibilitas perusahaan, yang pada gilirannya anak perusahaan akan bergerak Sebagai pure corporate. Bentuknya dapat berupa: financial (investment), holding company, strategic holding company (dengan jenis varian yang ada), atau 
Rustam Magun Pikahulan dan A6d Karim Faiz:

Analisis Yuridis tentang Kebijakan Holding Terhadap Badan Usaha Milik $\mathcal{N}$ egara $(\mathcal{B} U \mathcal{M} \mathcal{N})$ Sektor Pertambangan

operational holding company, yang tergantung dari perbedaan karakteristik anak perusahaan, value yang diharapkan dari holding.

Oleh karena itu,pengalihan saham dengan cara holding terhadap ketiga BUMN sektor pertambangan tersebut sudah tepat kebijakan ini dan kebijakan ini harus menunjukan capainnya melalui kinerja dari induk holding dan anggota holding BUMN sector pertambangan. Sehingga dapat menutupi kesalahan atau kekurangan pemerintah yang selama melakukan kebijakan privatisasi yang dilakukan dengan metode Initial Public Offering (IPO) atau penawaran saham perdana yang dinilai kurang efektif. ${ }^{25} \mathrm{Jadi}$, dengan adanya holding BUMN pada sektor pertambangan maka penilaian terhadap holding BUMN bukan semata-mata dimaknai sebagai pengalihan saham perusahaan BUMN atau hilang status persero.Akan tetapi dengan adanya metode holding BUMN,dapat dijadikan sebagai metode dan cara pembenahan BUMN untuk mencapai beberapa sasaran sekaligus, termasuk di dalamnya adalah peningkatan kinerja dan nilai tambah perusahaan, perbaikan struktur keuangan dan manajemen, penciptaan struktur industri yag sehat dan kompetitif, pemberdayaan BUMN mampu bersaing dan berorientasi global, penyebaran kepemilikan oleh publik serta pengembangan modal domestik.

Sehingga penulis berpendapat bahwa holding BUMN sektor pertambangan sudah sejalan dan tidak menyimpang dari dengan Undang-Undang Nomor 19 Tahun 2003 Tentang BUMN.Karena keberadaan Peraturan Pemerintah Nomor 47 tahun 2017 tentang Holding BUMN Pertambangan adalah untuk melaksanakan ketentuan Pasal 4 ayat (4) Undang-Undang Nomor 19 Tahun 2003 tentang Badan Usaha Milik Negara. Sehingga pemerintah perlu menetapkan Peraturan Pemerintah tentang Penambahan Penyertaan Modal Negara Republik Indonesia ke dalam Modal Saham Perusahaan Perseroan (Persero) PT Indonesia Asahan Aluminium.Sebagaimana yang telah ditegaskan atau diterangkan dalam Pasal 4 ayat (4) Undang-Undang Nomor 19 Tahun 2003 tentang Badan Usaha Milik Negara menyatakan bahwa, Setiap perubahan penyertaan modal negara sebagaimana dimaksud dalam ayat (2), baik berupa penambahan maupun 
Rustam Magun Pikahulan dan A6d Karim Faiz:

Analisis Yuridis tentang Kebijakan Holding Terhadap Badan Usaha

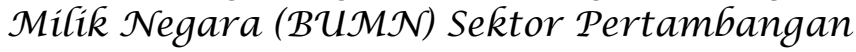

pengurangan, termasuk perubahan struktur kepemilikan negara atas saham Persero atau perseroan terbatas, ditetapkan dengan Peraturan Pemerintah. ${ }^{26}$

Dengan dikeluarkannya Peraturan Pemerintah Republik Indonesia Nomor 47 Tahun 2017 Tentang Penambahan Penyertaan Modal Negara Republik Indonesia Ke Dalam Modal Saham Perusahaan Perseroan (Persero) PT Indonesia Asahan Aluminium.Penulis menilai bahwa, ini merupakanupaya yang tidak bertentangan dengan Undang-Undang Nomor 19 Tahun 2003 Tentang BUMN, hal ini dikarenakan dalam Pasal 4 ayat (3) telah menegaskan bahwa Setiap penyertaan modal negara dalam rangka pendirian BUMN atau perseroan terbatas yang dananya berasal dari Anggaran Pendapatan dan Belanja Negara ditetapkan dengan Peraturan Pemerintah. Oleh karena itu, keberadaan atauterbentuknya Peraturan Pemerintah Nomor 47 Tahun 2017 selainjuga menjalankan amanah Undang-Undang Nomor 19 Tahun 2003 Tentang BUMN, PP terebut merupakan payung hukum dari terbentuknya holding BUMN tambang.

Oleh karena itu, arah dan kebijakan pengalihan saham BUMN pada sektor pertambangan dengan metode holding terhadap ketiga BUMN tersebut adalah untuk mengalihkan saham pemerintah dari ketiga perusahan BUMN tembang tersebut kepada induk holding yakni PT Inalum (Persero). Tujuannya pun sudah jelas yakni memperkuat struktur permodalan dan meningkatkan kapasitas usaha Perusahaan Perseroan (Persero) PT Indonesia Asahan Aluminium.Dengan adanya holding BUMN pertambangan maka, sinergi ketiga BUMN pertambangan tersebut dapat meningkatkan efisiensi dan kekuatan finansial sehingga memudahkan pengembangan usaha khususnya di bidang hilirisasi. Dengan adanya holding, BUMN diharapkan akan semakin fokus untuk mengembangkan bisnisnya dari hulu ke hilir sehingga dapat meningkatkan stabilitas BUMN, efisiensi dan tentunya keuntungan yang lebih besar bagi negara.

\section{PENUTUP}

Kebijakan Holding BUMN sektor pertambangan pada tiga BUMN yang dilakukan oleh pemerintah menurut penulis sudah mengikuti prosedur hukum dan perundang-undangan di indonesia. Sehingga keberadaan Peraturan Pemerintah 
Rustam Magun Pikahulan dan A6d Karim Faiz:

Analisis Yuridis tentang Kebijakan Holding Terhadap Badan Usaha

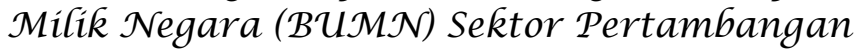

Nomor 47 tahun 2017 tentang Holding BUMN Pertambangan merupakan pelakasana dan berdasar pada ketentuan Pasal 4 ayat (4) Undang-Undang Nomor 19 Tahun 2003 tentang Badan Usaha Milik Negara. Olehnya itu, Peraturan Pemerintah tentang Penambahan Penyertaan Modal Negara Republik Indonesia ke dalam Modal Saham Perusahaan Perseroan (Persero) PT Indonesia Asahan Aluminium berserta kedudukannya sudah jelas dan kebijakan ini sudah sesuai mekanisme yang ada. Di tambah lagi dengan adanya penegasan dalam pasal 4 Undang-undang BUMN bahawa untuk setiap perubahan penyertaan modal Negara, baik berupa penambahan maupun pengurangan, termasuk perubahan struktur kepemilikan negara atas saham Persero atau perseroan terbatas, harus ditetapkan dengan Peraturan Pemerintah.

Secara yuridis pengambilalihan ketiga saham BUMN yang bergerak pada sektor pertambangan tersebut yang dilakukan melalui proses holding oleh PT Indonesia Asahan Aluminium selaku induk holding.Penulis menyimpulkan bahwa, Telah mengikuti prosedur berdasar atas Undang-undang yang ada. Hal ini teah dimanatkan dalam Undang-Undang BUMN Pasal 63 ayat (2) UndangUndang BUMN yaitu Suatu BUMN dapat mengambil alih BUMN dan/atau perseroan terbatas lainnya. Oleh karena itu, dalam proses pengambilalihan ketiga BUMN tesebut dengan cara menghilangkan status Persero, secara prosedural sesuai dengan Undang-Undang Nomor 19 Tahun 2003 Tentang BUMN. Ditambah lagi dengan posisi dari pada PT Indonesia Asahan Aluminium adalah $100 \%$ milik pemerintah, sehingga walaupun ketiga BUMN tersebut alihkan sahamnya dengan cara holding tetap akan berada dibawah kendali pemerintah.

\section{Catatan Akhir}

${ }^{1}$ Heidrachman Ranupandojo,1990, Dasar-dasar ekonomi perusahaan, Yogyakarta: Unit penerbit danpercetakan AMP YPN, hlm.1, dikutip dari Skrpsi Arya Devendra Fatzgani, Tinjauan Hukum Terhadap Pembentukan Induk Perusahaan (Holding) Pada Badan Usaha Milik Negara, Fakultas Hukum Universitas Hasanuddin, 2017, hlm. 2

${ }^{2}$ Mahmudin Yasin, 2012, Membangun BUMN Berbudaya, Jakarta: BOOKNESIA Rakyat Merdeka Online (RMOL), hlm. 67.

3 Aminuddin Ilmar, 2004, Privatisasi BUMN di Indonesia, Makassar: Hasanuddin University Press, hlm. 15 
Rustam Magun Pikahulan dan A6d Karim Faiz: Analisis Yuridis tentang Kebijakan Holding Terhadap Badan Usaha

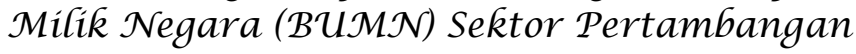

${ }^{4}$ Mohammad Hatta, 1980, Pelaksanaan Undang-Undang Dasar 1945 Pasal 33, dalam Penjabaran Pasal 33 UUD 1945 Jilid I, Cet. II, Jakarta: Mutiara, hlm. 28.

${ }^{5}$ Gatot Supramono, 2016, BUMN Ditinjau Dasri Segi Hukum Perdata, Jakarta: Rineka Cipta, hlm. 26

${ }^{6} \mathrm{https}: / /$ www.hukumonline.com/berita/baca/lt5a31d2429729b/untung-rugi-ketika-antam-bukit-asam--dan-timah-melepas-status-persero, diakses pada tanggal 04 September 2019 Pukul 11:30 WITA

${ }^{7}$ https://www.hukumonline.com/berita/baca/lt5a31d2429729b/untung-rugi-ketika-antam-bukit-asam--dan-timah-melepas-status-persero, diakses pada tanggal 04 September 2019 Pukul 11:30 WITAoip

${ }^{8}$ Munir Fuady, 2001, Hukum Tentang Akuisisi, Take Over dan LBO, Jakarta: PT Citra Aditya Bakti , hlm. 4-5

${ }^{9}$ Sumber Laporan: https://finance.detik.com/bursa-dan-valas/d-3728759/antam-hinggatimah-tak-lagi-bumn-pemerintah-tetap-dikontrol-negara, diakses pada tanggal 22 Agustus 2019 Pukul 18:57 WITA

${ }^{10} \mathrm{https} / / /$ tirto.id/di-balik-ambisi-menyatukan-4-bumn-tambang-czVT, diakses pada tanggal 04 September 2019 pukul 12:22 WITA

${ }^{11}$ https://ekonomi.kompas.com, 14/11/2017, 18:35 WIB Penulis : Sakina Rakhma Diah Setiawan, diakses pada tanggal 22 Agustus 2019 Pukul 19:07 WITA WITA

${ }^{12}$ https://economy.okezone.com/, diakses pada tanggal 22Agustus 2019 Pukul 19:17

${ }^{13} \mathrm{https} / / /$ www.rappler.com/indonesia/berita/189848-holding-bumn-tambang-jalan-kuasaifreeport, diakses pada tanggal 04 September 2019 Pukul 12:38 WITA

${ }^{14} \mathrm{https}: / /$ kominfo.go.id/content/detail/9521/holding-bumn-industri-pertambanganbersinergi-menjadi-perusahaan-kelas-dunia/0/artikel_gpr, diakses pada tanggal 05 September 2019 pukul 08:56 WITA

${ }^{15}$ Pertimbangan Peraturan Pemerintah Nomor 47 Tahun 2017 Tentang Penambahan Penyertaan Modal Negara Republik Indonesia Ke Dalam Modal Saham Perusahaan Perseroan (Persero) PT Indonesia Asahan Aluminium.

${ }^{16} \mathrm{https}: / /$ www.cnnindonesia.com/ekonomi/20171120133122-85-256855/holding-bumntambang-tetap-dalam-kendali-pemerintah, diakses pada tanggal 22 Agustus 2019 pukul 12:09 WITA

${ }^{17}$ Pasal 2A ayat (1) Peraturan Pemerintah Nomor Nomor 72 Tahun 2016 Tentang Perubahan Atas Peraturan Pemerintah Nomor 44 Tahun 2005 Tentang Tata Cara Penyertaan Dan Penatausahaan Modal Negara Pada Badan Usaha Milik Negara Dan Perseroan Terbatas.

${ }^{18}$ Pasal 2A ayat (2) Peraturan Pemerintah Nomor Nomor 72 Tahun 2016 Tentang Perubahan Atas Peraturan Pemerintah Nomor 44 Tahun 2005 Tentang Tata Cara Penyertaan Dan Penatausahaan Modal Negara Pada Badan Usaha Milik Negara Dan Perseroan Terbatas.

${ }^{19}$ Said Didu dalam https://www.cnnindonesia.com, diakses pada tanggal 22 Agustus 2019 Pukul 12:36 WITA

${ }^{20}$ Pasal 1 Ayat (1) Peraturan Pemerintah Nomor 26 Tahun 2014 tentang Penetapan PT Indonesia Asahan Aluminium Sebagai Perusahaan Perseroan (Persero) PT Indonesia Asahan Aluminium. 
Rustam Magun Pikahulan dan A6d Karim Faiz:

Analisis Yuridis tentang Kebijakan Holding Terhadap Badan Usaha Milik $\mathcal{N}$ egara $(\mathcal{B} U \mathcal{M} \mathcal{N})$ Sektor Pertambangan

\footnotetext{
${ }^{21}$ Pasal 3 Peraturan Pemerintah Nomor 26 Tahun 2014 tentang Penetapan PT Indonesia Asahan Aluminium Sebagai Perusahaan Perseroan (Persero) PT Indonesia Asahan Aluminium.

${ }^{22}$ https://www.rappler.com/indonesia/berita/189848-holding-bumn-tambang-jalan-kuasaifreeport, diakses pada tanggal 22 Agustus 2018 Pukul 13:31 WIB

${ }^{23} \mathrm{https} / / /$ www.rappler.com/indonesia/berita/189848-holding-bumn-tambang-jalan-kuasaifreeport, diakses pada tanggal 22 Agustus 2018 Pukul 13:31 WIB

${ }^{24}$ Sumber: https://www.rappler.com/indonesia, diakses pada tanggal 22 Agustus 2019 pukul 13:53 WITA

${ }^{25}$ Juajir Sumardi, 2012, Hukum perusahaan transnasional dan franchise, Makasar: Arus Timur, hlm. 78

${ }^{26}$ Pasal 4 ayat (4) Undang-Undang Nomor 19 Tahun 2003 tentang Badan Usaha Milik Negara
}

\section{DAFTAR PUSTAKA}

Aminuddin Ilmar, Privatisasi BUMN di Indonesia, Makassar: Hasanuddin University Press, 2004.

Arya Devendra Fatzgani, Tinjauan Hukum Terhadap Pembentukan Induk Perusahaan (Holding) Pada Badan Usaha Milik Negara, Fakultas Hukum Universitas Hasanuddin, 2017.

Gatot Supramono, BUMN Ditinjau Dasri Segi HukumPerdata, Jakarta: Rineka Cipta, 2016.

Heidrachman Ranupandojo, Dasar-dasar ekonomi perusahaan, Yogyakarta: Unit penerbit dan percetakan AMP YPN, 1990.

https://economy.okezone.com/, diakses pada tanggal 22 Agustus 2019 Pukul 19:17 WITA

https://ekonomi.kompas.com, 14/11/2017, 18:35 WIB Penulis : Sakina Rakhma Diah Setiawan, diakses pada tanggal 22 Agustus 2019 Pukul 19:07 WITA

https://finance.detik.com/bursa-dan-valas/d-3728759/antam-hingga-timah-taklagi-bumn-pemerintah-tetap-dikontrol-negara

https://tirto.id/di-balik-ambisi-menyatukan-4-bumn-tambang-czVT, diakses pada tanggal 22 Agustus 2019 Pukul 20;09 WITA

https://www.cnnindonesia.com/ekonomi/20171120133122-85-256855/holdingbumn-tambang-tetap-dalam-kendali-pemerintah, diakses pada tanggal 22 Agustus 2019 pukul 12:09 WITA

https://www.rappler.com/indonesia/berita/189848-holding-bumn-tambang-jalankuasai-freeport, diakses pada tanggal 22 Agustus 2018 Pukul 13:31 WITA 
Rustam Magun Pikahulan dan A6d Karim Faiz:

Analisis Yuridis tentang Kebijakan Holding Terhadap Badan Usaha

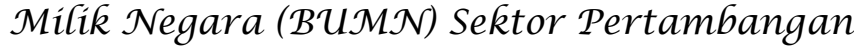

Juajir Sumardi, Hukum perusahaan transnasional dan franchise, Makasar: Arus Timur, 2012.

Mahmudin Yasin, Membangun BUMN Berbudaya, Jakarta: BOOKNESIA Rakyat Merdeka Online (RMOL),2012.

Mohammad Hatta, Pelaksanaan Undang-Undang Dasar 1945 Pasal 33, dalam Penjabaran Pasal 33 UUD 1945 Jilid I, Cet. II, Jakarta: Mutiara, 1980.

Munir Fuady, Hukum Tentang Akuisisi, Take Over dan LBO, Jakarta: PT Citra Aditya Bakti, 2001. :

Peraturan Pemerintah Nomor 26 Tahun 2014 tentang Penetapan PT Indonesia Asahan Aluminium Sebagai Perusahaan Perseroan (Persero) PT Indonesia Asahan Aluminium.

Peraturan Pemerintah Nomor 26 Tahun 2014 tentang Penetapan PT Indonesia Asahan Aluminium Sebagai Perusahaan Perseroan (Persero) PT Indonesia Asahan Aluminium.

Peraturan Pemerintah Nomor Nomor 72 Tahun 2016 Tentang Perubahan Atas Peraturan Pemerintah Nomor 44 Tahun 2005 Tentang Tata Cara Penyertaan Dan Penatausahaan Modal Negara Pada Badan Usaha Milik Negara Dan Perseroan Terbatas.

Pertimbangan Peraturan Pemerintah Nomor 47 Tahun 2017 Tentang Penambahan Penyertaan Modal Negara Republik Indonesia Ke Dalam Modal Saham Perusahaan Perseroan (Persero) PT Indonesia Asahan Aluminium.

Undang-Undang Nomor 19 Tahun 2003 tentang Badan Usaha Milik Negara 